\title{
In vivo compatibility between Beauveria bassiana (Bals.) Vuillemin and castor oil on Hypothenemus hampei (Ferrari)
}

\author{
Flávio Neves Celestino1 (D), Dirceu Pratissoli (D), \\ Hugo José Gonçalves dos Santos Junior² ${ }^{2}$, Lorena Contarini Machado ${ }^{2}$ (D)
}

\begin{abstract}
${ }^{1}$ Instituto Federal de Educação, Ciência e Tecnologia do Sudeste de Minas Gerais/IFSUDESTE-MG, Campus Manhuaçu, Manhuaçu, MG, Brasil
${ }^{2}$ Universidade Federal do Espírito Santo/UFES, Centro de Ciências Agrárias, Alegre, ES, Brasil

Contact authors: fncelestino@yahoo.com.br, dirceu.pratissoli@gmail.com; hugo.goncalvesjr@gmail.com, lorenarini@hotmail.com

Received in May 25, 2020 and approved in January 5, 2021
\end{abstract}

\begin{abstract}
The degree of in vivo compatibility between the entomopathogenic fungi Beauveria bassiana (Bals.) Vuillemin (Ascomycota: Hypocreales) and castor oil is important, as the interaction can be additive, synergistic or antagonistic. Thus, the objective of this study was to evaluate the in vivo compatibility between castor oil and B. bassiana on the coffee berry borer. The CCA-UFES/Bb-4 isolate of B. bassiana was used in concentrations of 0.0 (control), $1 \times 10^{4}, 1 \times 10^{5}$, $1 \times 10^{6}$ and $1 \times 10^{7}$ conidia $\mathrm{mL}^{-1}$. The concentrations of castor oil were: 0.0 (control), $0.5,1.0,1.5,2.0,2.5$ and $3.0 \% \mathrm{v} \mathrm{v}$. The total and confirmed mortality were evaluated, and data submitted to variance analysis. To verify the effect of $B$. bassiana and castor oil concentrations, the data were submitted to regression analysis at $5 \%$ probability. Castor oil had an antagonistic effect on $B$. bassiana reducing the mortality of coffee berry borer. The mortality of $H$. hampei reduced caused by interaction between $B$. bassiana and castor oil, due to increasing concentration of castor oil. Lower interference of castor oil was observed for high concentrations of $B$. bassiana. Based on the results, management of $H$. hampei cannot be normally performed using the association between castor bean oil and B. bassiana, except if the economic viability of the higher concentrations justified.
\end{abstract}

Key words: Ricinus communis; Botanical insecticides; Biological control; Phytosanitary pest management; Coffee crop.

\section{INTRODUCTION}

Coffee (Coffea arabica L. and Coffea canephora Pierre ex Froehner) is the tropical agricultural product most exported in the world and in 2015 the global coffee industry generated approximately 200 billion dollars (International Coffee Organization - OIC, 2019 Samper; Giovannucci; Vieira, 2020). In addition, coffee is also one of the most important commodities for Brazilian economy (Ministério da Agricultura, Pecuária e Abastecimento -MAPA, 2020a). However, the coffee berry borer, Hypothenemus hampei (Ferrari) (Coleoptera: Curculionidae: Scolytinae), is one of the most important biotic factors that negatively affects coffee planting (Vega et al., 2014). This pest destructs fruits, reduces weight of beans, changes coffee type, classification and beverage taste (Vega et al., 2009). Thus, it is estimated that in Brazil, losses around 215 and 358 million dollars per year occur, just by $H$. hampei direct damages (Oliveira et al., 2013).

To reduce losses caused by coffee berry borer, effective management methods are necessary, due to the difficulties to control it inside coffee beans. Chemical method is the main used by farmers, however it presents several problems, such as an insufficient number of active ingredients, leading to the selection of resistant strains, and consequently to low efficiency (Campos et al., 2019; MAPA, 2020b). In addition, it can also cause environmental problems, such as elimination of beneficial fauna and increasing contamination of soil, water, atmosphere and living beings (Molina et al., 2014; Campos et al., 2019).
Such problems have driven research into new management methods, emphasizing the use of botanical insecticides and biological control (Dara, 2019). In the last decades, promising results have been obtained using compounds derived from aromatic plants to control agricultural pests (Isman; Grieneisen, 2014; Campos et al., 2019). Among these plants, castor bean (Ricinus communis L.) has shown toxicity to several pests, among them the coffee berry borer, either through the use of oil and/or extracts or by isolated compounds such as ricinin, ricinoleic acid and albumins 2S, Ric c 1 and Ric c 3 (Bigi et al., 2004; Ramos-López et al., 2010; Arnosti et al., 2011; Tounou et al., 2011; Nascimento et al., 2011; Celestino et al., 2015; 2016a; Machado et al., 2020).

Beauveria bassiana (Bals.) Vuillemin (Ascomycota: Hypocreales) stands out as one of the most important biological pest control agents in the biological control context (Vega et al., 2009; Celestino et al., 2018). Some factors that justify the interest in this fungi include its mass production "in vitro", its wide genetic variability, possibility of use in organic crops, as well as, reduction in the use of synthetic chemical insecticides (Dalvi et al., 2011; Islam; Omar, 2012). In addition, it is noteworthy that $B$. bassiana is a registered biopesticide for a wide range of hosts, approximately 700 species of insect-pests, including H. hampei (Swathi; Visalakshy; Das, 2018).

In Colombia, since the arrival of the coffee berry borer in 1988, several researches were initiated by the National Coffee Research Center (Cenicafé), aiming at the biological 
control of this pest. There, the success of the use of $B$. bassiana is due, among other reasons, to the shaded cultivation of the coffee tree, which provides sufficient protection against solar radiation and optimal levels of relative humidity at certain times of the day (Correal et al., 2018). This fact differs from Brazil, where most of the coffee plantations are carried out in full sun, being important the development of researches that aim to make compatible the association of methods that can confer protection against solar radiation and, also, help in the maintenance of humidity.

Although entomopathogenic fungi allow association with other management methods, it is necessary to study the degree of compatibility between them, since interaction can be additive, synergistic, or antagonistic (Islam; Omar, 2012; Celestino el al., 2018). Compatibility between vegetable oils and entomopathogenic fungi has some advantages, as they can be certified and used in organic crops; they are generally more viscous and, therefore, give greater adhesion to the surface of insects and plants; they are not flammable and safer; they provide some protection to spores against ultraviolet radiation and evaporate less than mineral oils (Alves; Faria, 2010). Therefore, in addition to in vitro compatibility testing, the in vivo testing is also important, since during insect infection process, numerous factors may be involved and affect the interaction between methods (Fang et al., 2005; Mohan et al., 2007; Islam; Olleka; Ren, 2010; Pedrini et al., 2010; Rondelli et al., 2011; Zhang et al., 2012). Thus, the objective of this study was to evaluate in vivo compatibility between castor oil and B. bassiana on coffee berry borer.

\section{MATERIAL AND METHODS}

The experiment was carried out in the sector of Entomology of the Nucleus of Scientific and Technological Development in Phytosanitary Management (NUDEMAFI) from Agricultural Sciences Center at the Federal University of Espírito Santo (CCA-UFES), in Alegre - ES.

\subsection{Creation and maintenance of $\mathrm{H}$. hampei}

Creation and maintenance of coffee berry borer was carried out according to Celestino et al. (2016b), in an airconditioned room at $25 \pm 2{ }^{\circ} \mathrm{C}$, relative humidity $(\mathrm{RH})$ of 60 $\pm 10 \%$ and photophase of $12 \mathrm{~h}$. The brocaded coffee fruits of Coffea canephora Pierre ex Froehner were collected in the field, in the municipality of Jerônimo Monteiro - ES (latitude: $-20^{\circ} 47^{\prime} 22^{\prime \prime}$ and longitude: $\left.-41^{\circ} 23^{\prime} 42^{\prime \prime}\right)$.

\subsection{Acquisition and production of B. bassiana}

The CCA-UFES/Bb-4 isolate from collection of the Bank of Entomopathogens of the CCA-UFES was used, which was previously evaluated in previous studies that proved its virulence to coffee berry borer (Dalvi et al., 2011). To be sure of pathogenicity and virulence, the isolate was previously reinvigorated in adults of coffee berry borer. During the bioassays, the fungi were grown in a PDA culture medium (potato-dextrose-agar) plus yeast and, after approximately ten days, they were multiplied in Petri dishes containing PDA plus yeast. They were incubated in an air-conditioned chamber at $25 \pm 1{ }^{\circ} \mathrm{C}$, RH of $70 \pm 10 \%$ and photophase of $12 \mathrm{~h}$, where they remained for ten days.

\subsection{Extraction and characterization of castor oil}

The seeds of IAC 80 variety of $R$. communis plant were purchased from the Agronomic Institute of Campinas (IAC). The oil was extracted using the cold pressing method. Castor oil was stored in a container covered with aluminum foil and hermetically sealed. The castor oil used showed physicalchemical characteristics according to Celestino et al. (2016a) (Table 1).

Table 1: Physico-chemical characteristics of vegetable oils.

\begin{tabular}{cc}
\hline Chemical composition $(\%)^{(1)}$ & Castor bean \\
\hline Palmitic acid $\left(\mathrm{C}_{16: 0}\right)$ & 0.70 \\
Stearic acid $\left(\mathrm{C}_{18: 0}\right)$ & 0.90 \\
Oleic acid $\left(\mathrm{C}_{18: 1}\right)$ & 2.80 \\
Ricinoleic Acid $\left(\mathrm{C}_{18: 1}\right)$ & 90.20 \\
Linoleic acid $\left(\mathrm{C}_{18: 2}\right)$ & 4.40 \\
Linolenic Acid $\left(\mathrm{C}_{18: 3}\right)$ & 0.20 \\
\hline Chemical constant & \\
\hline Saponification $(\mathrm{mg} / \mathrm{KOHg})$ & 182.90 \\
Iodine $(\mathrm{g} \mathrm{I} / 100 \mathrm{~g})$ & 84.50 \\
\hline Physical constant & 1.479 \\
\hline Refractive index $\left(40^{\circ} \mathrm{C}\right)$ & 332.00 \\
Viscosity $(\mathrm{cP})\left(30^{\circ} \mathrm{C}\right)$ & \\
\hline
\end{tabular}

(1)Number of carbon atoms: number of double bonds; (2) Composition of the oil used in the experiment according to Celestino et al. (2016a).

\subsection{Compatibility between castor oil and B. bassiana}

The experiments were carried out in an airconditioned chamber at $25 \pm 1{ }^{\circ} \mathrm{C}$, RH of $70 \pm$ $10 \%$ (a condition necessary for experiments with entomopathogenic fungi that require high humidity) and photophase of $12 \mathrm{~h}$. Suspensions of the B. bassiana isolate were adjusted to the following concentrations: 0.0 (control), $1 \times 10^{4}, 1 \times 10^{5}, 1 \times 10^{6}$ and $1 \times 10^{7}$ conidia $\mathrm{mL}^{-1}$ in order to evaluate the compatibility. Castor oil concentrations were as follows: 0.0 (control), $0.5,1.0,1.5$, $2.0,2.5$ and $3.0 \% \mathrm{v} \mathrm{v}^{-1}$. Thus, association of fungi and castor oil concentrations corresponded to 35 treatments. In the 
preparation of suspensions, an adhesive spreader (Tween ${ }^{\mathbb{R}}$ 80 PS; Company: Dinâmica Química Contemporânea LTDA, Diadema, SP) was used at $0.05 \% \mathrm{v} \mathrm{v}^{-1}$.

The experimental units consisted of an acrylic box $\left(\right.$ gerbox $\left.^{\circledR}\right)(6 \mathrm{~cm}$ in diameter $\mathrm{x} 2 \mathrm{~cm}$ in height) lined with filter paper and containing 15 adult females of $H$. hampei. The spraying on the females of coffee berry borer was performed with Potter's Tower ${ }^{\circledR}$ at a pressure of 15 pounds in ${ }^{-2}$, applying a volume of $5.5 \mathrm{~mL}$ per repetition. Thus, with the pressure and volume used in the Potter's Tower, an average volume of $1.78 \mathrm{mg} \mathrm{cm}^{-2}$ was deposited, varying from 1.43 to 2.08 $\mathrm{mg} \mathrm{cm}^{-2}$ according to the recommendation of IOBC/WPRS ("International Organization for Biological and Integrated Control of Noxious Animals and Plants/West Paleartic Regional Section"), which is a deposit of 1.5 to $2.0 \mathrm{mg} \mathrm{cm}^{-2}$ for glass or sheet surfaces (Overmeer; Van Zon, 1982). After spraying, 0.15 grams of ground coffee/gerbox ${ }^{\circledR}$ was offered as food.

The experimental design was completely randomized, with 5 repetitions, in a factorial arrangement $5 \times 7$ (B. bassiana concentrations $\mathrm{x}$ castor oil concentrations). Mortality evaluations was performed daily until the seventh day and the dead individuals were transferred to moist chambers in order to confirm the etiological agent. The wet chamber consisted of an acrylic box $\left(\right.$ gerbox $\left.^{\circledR}\right)(6 \mathrm{~cm}$ diameter $\mathrm{x} 2 \mathrm{~cm}$ height), in which a cotton pad moistened in the lid was placed and identified according to the treatment and repetition. After 10 days the cadavers were examined to check presence or absence of fungi.

The data of total mortality and confirmed mortality were submitted to variance analysis and to verify the effect of B. bassiana and castor oil concentrations, they were submitted to regression analysis, at $5 \%$ probability. Maximum mortality points were determined for the results that fitted to hyperbolic model. From these data, the concentration was determined to obtain $90 \%$ of maximum mortality point, according to the equations below:

\section{$\mathrm{X}=\left(\beta_{1}{ }^{*}(0.9 * \mathrm{PMM})\right) /(\mathrm{PMM}-(0.9 * \mathrm{PMM}))$}

$\beta_{1}=$ estimated parameter; $\mathrm{PMM}=$ point of maximum mortality.

Regression analysis was also performed, using the response surface methodology based on hyperbolic model with two independent variables, given by:

$Z=\left(\beta_{0}+\beta_{1} X_{1}+\beta_{2} X_{1}^{2}+\beta_{3} X_{1} Y_{1}\right) /\left(\beta_{4}+X_{1}\right)$

$\mathrm{Z}=$ Parameter analyzed (total mortality); $\mathrm{X} 1=B$. bassiana concentration; $\mathrm{Y} 1=$ Castor oil concentration; $\beta \mathrm{i}$, with i ranging from 0 to $4=$ estimated parameters.
The model presented above was chosen based on equation that best fitted to the data, based on coefficient of determination $\left(\mathrm{R}^{2}\right)$ and betas significance $(\beta)$ and regression by $\mathrm{F}$ test, at $5 \%$ probability.

\section{RESULTS}

The results obtained in this bioassay showed interaction between $B$. bassiana concentration and castor oil concentration on total and confirmed mortality of coffee berry borer (Figure 1, Figure 2).

Any model fitted to total and confirmed mortalities of coffee berry borer with 0.0 and $1 \times 10^{4}$ conidia $\mathrm{mL}^{-1}$ of B. bassiana, remaining constant in response to castor oil concentrations (Figure 1). However, for $1 \times 10^{5}$ and $1 \times 10^{6}$ conidia $\mathrm{mL}^{-1}$, the total and confirmed mortality of $H$. hampei fitted to linear model, where mortality reduced due to increasing castor oil concentration (Figure 1). Although B. bassiana concentrations show the same behavior for total and confirmed mortality of $H$. hampei due to castor oil concentrations, a higher intercept value is observed in $1 \times 10^{6}$ conidia $\mathrm{mL}^{-1}$ i.e., higher mortality (Figure 1). Unlike previous concentrations, for $1 \times 10^{7}$ conidia $\mathrm{mL}^{-1}$ of $B$. bassiana, any model fitted to total mortality of coffee berry borer, remaining constant according to castor oil concentrations, with total average mortality of $90.49 \%$ (Figure 1). However, the confirmed mortality for this concentration fitted to linear model, reducing mortality due to the increase in castor oil concentration (Figure 1). When this confirmed mortality is compared to that presented by $1 \mathrm{x}$ $10^{5}$ and $1 \times 10^{6}$ conidia $\mathrm{mL}^{-1}$, a much lower slope is observed, which shows lower influence of castor oil on mortality of $H$. hampei in high fungi concentrations (Figure 1).

Analyzing the total and confirmed mortality of coffee berry borer from concentrations of castor oil in response to concentrations of $B$. bassiana, it was observed that $0.0,0.5$, $1.0,1,5$ and $2.0 \% \mathrm{v} \mathrm{v}^{-1}$ of castor oil, the mortalities fitted to a hyperbolic model, in which, the mortality tends to increase in response to $B$. bassiana concentrations until reaching a certain point and from then on, increases on mortality is insignificant and practically constant (Figure 2). However, in high castor oil concentrations, 2.5 and $3.0 \% \mathrm{v} \mathrm{v}^{-1}$, the total and confirmed mortality fitted to a linear model, presenting an increase in $H$. hampei mortality due to the increase in $B$. bassiana concentration (Figure 2).

For concentrations that fitted to hyperbolic model, it is possible to determine the oil concentration that gives maximum coffee berry borer mortality (Table 2). For statistical determination it was observed that $0.0,0.5,1.0,1.5$ and $2.0 \%$ $\mathrm{v} \mathrm{v}^{-1}$ of castor oil and $1 \times 10^{7}$ conidia $\mathrm{mL}^{-1}$ of $B$. bassiana was the one that conferred maximum total mortality and confirmed mortality (Table 2). In addition to the previous inference, $B$. 

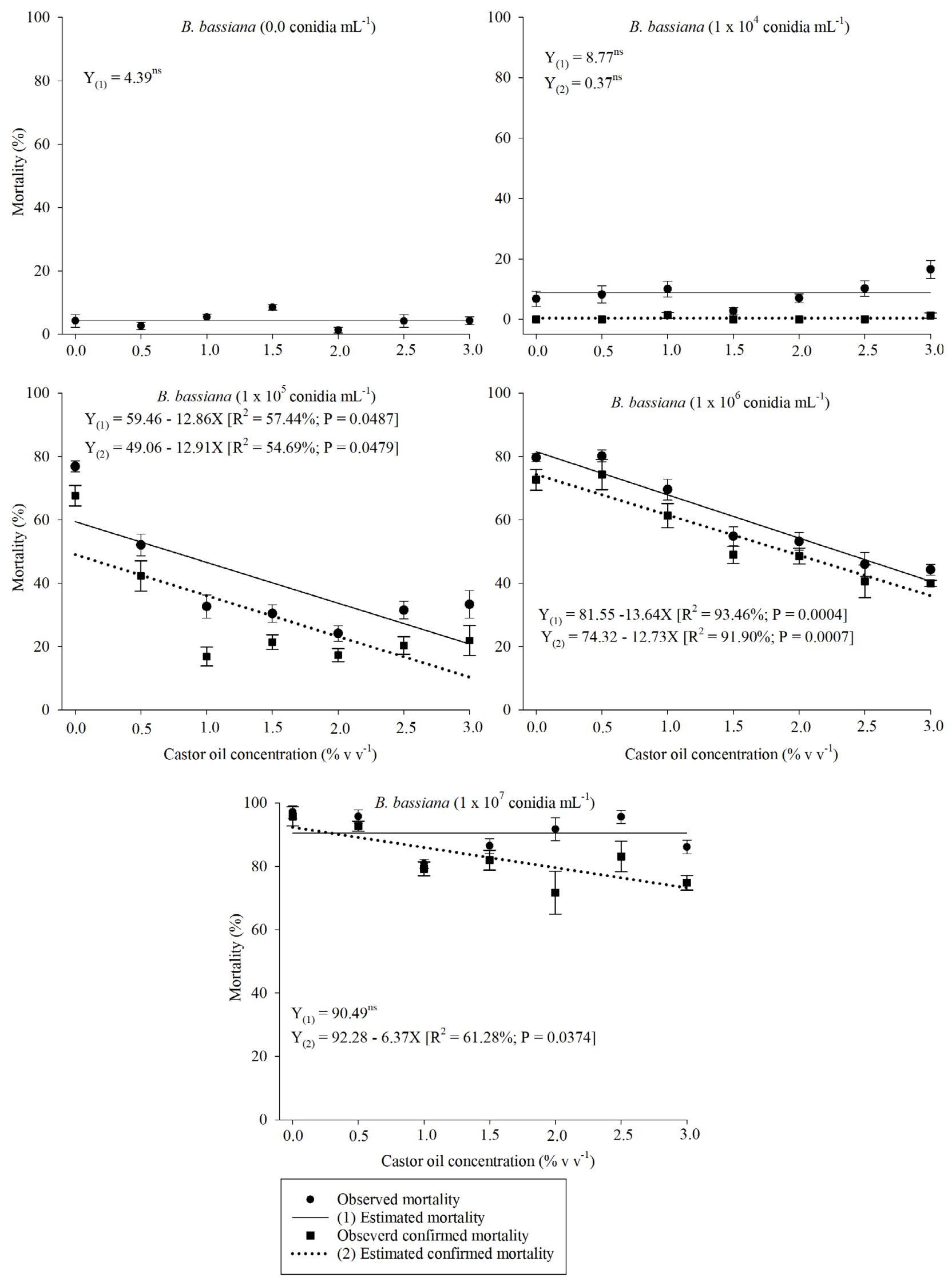

Figure 1: Mortality of Hypothenemus hampei caused by interaction between Beauveria bassiana and castor oil in different concentrations, at $25 \pm 1{ }^{\circ} \mathrm{C}, \mathrm{RH}$ of $70 \pm 10 \%$ and $12 \mathrm{~h}$ photophase. 

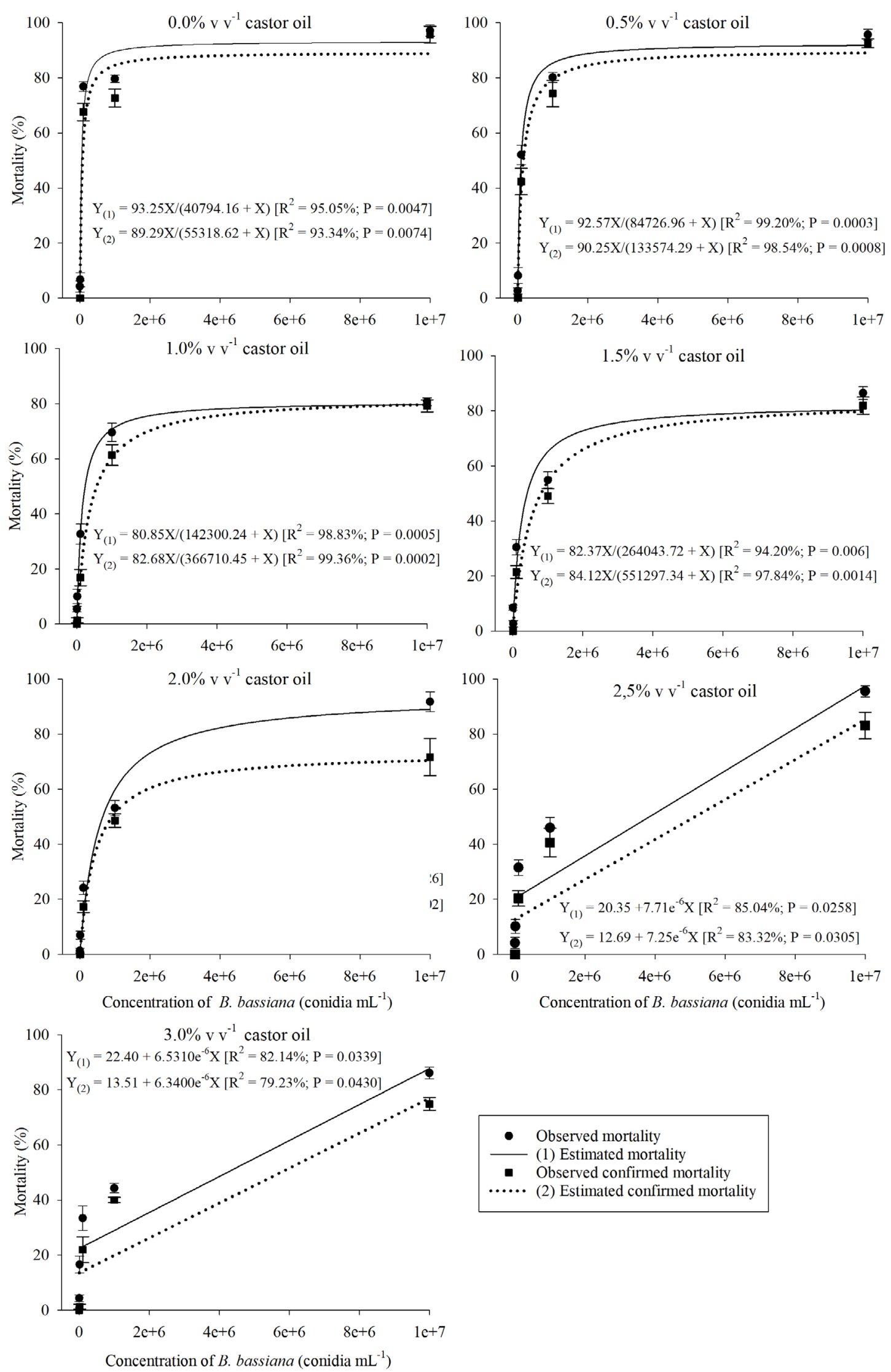

- Observed mortality (1) Estimated mortality

Observed confirmed mortality

(2) Estimated confirmed mortality

Figure 2: Mortality of Hypothenemus hampei caused by interaction between castor oil and Beauveria bassiana in different concentrations, at $25 \pm 1^{\circ} \mathrm{C}, \mathrm{RH}$ of $70 \pm 10 \%$ and $12 \mathrm{~h}$ photophase. 
bassiana concentration necessary to reach $90 \%$ of maximum mortality of coffee berry borer was determined, where it was observed reductions in concentration of up to 27.24 times for total mortality and 20.09 times for confirmed mortality in absence of castor oil (Table 2). From the results obtained, it is possible to determine the economic viability of a given concentration in response to reduction in mortality and reduction in $B$. bassiana concentration (Table 2). Based on the level of economic damage, the results can be worked out to obtain the best economic response for management of coffee berry borer.

Table 2: Determination of maximum points and $90 \%$ of maximum mortality and respective concentrations, for hyperbolic equations (Figure 2).

\begin{tabular}{ccccccc}
\hline $\mathrm{COM}^{1}$ & $\mathrm{PMM}^{2}$ & $\mathrm{CBb}^{3}$ & $90 \% \mathrm{PMM}^{4}$ & $\mathrm{CBb}^{3}$ & $\mathrm{RM}^{5}$ & $\mathrm{RC}^{6}$ \\
\hline \multicolumn{7}{c}{ Total Mortality } \\
\hline 0.0 & 93.25 & $1 \times 10^{7}$ & 83.93 & $3.67 \times 10^{5}$ & 9.32 & 27.24 \\
0.5 & 92.57 & $1 \times 10^{7}$ & 83.13 & $7.62 \times 10^{5}$ & 9.44 & 13.11 \\
1.0 & 80.85 & $1 \times 10^{7}$ & 72.77 & $1.28 \times 10^{6}$ & 8.08 & 7.81 \\
1.5 & 82.37 & $1 \times 10^{7}$ & 74.13 & $2.38 \times 10^{6}$ & 8.24 & 4.21 \\
2.0 & 94.13 & $1 \times 10^{7}$ & 84.72 & $5.18 \times 10^{6}$ & 9.41 & 1.93 \\
\hline \multicolumn{7}{c}{ Confirmed Mortality } \\
0.0 & 89.29 & $1 \times 10^{7}$ & 80.36 & $4.98 \times 10^{5}$ & 8.93 & 20.09 \\
0.5 & 90.25 & $1 \times 10^{7}$ & 81.23 & $1.20 \times 10^{6}$ & 9.02 & 8.32 \\
1.0 & 82.68 & $1 \times 10^{7}$ & 74.41 & $3.30 \times 10^{6}$ & 8.27 & 3.03 \\
1.5 & 84.12 & $1 \times 10^{7}$ & 75.71 & $4.96 \times 10^{6}$ & 8.41 & 2.02 \\
2.0 & 73.47 & $1 \times 10^{7}$ & 66.12 & $3.90 \times 10^{6}$ & 7.35 & 2.56 \\
\hline
\end{tabular}

${ }^{1}$ Castor oil concentration; ${ }^{2}$ Point of maximum mortality; ${ }^{3}$ Beauveria bassiana concentration (conidia $\mathrm{mL}^{-1}$ ); ${ }^{4} 90 \%$ of maximum mortality; ${ }^{5}$ Reduction in mortality; ${ }^{6}$ Reduction in concentration (conidia $\mathrm{mL}^{-1}$ ).

The data were also analyzed by response surface to obtain a function where, from concentrations of castor oil and concentrations of $B$. bassiana, the coffee berry borer mortality caused by interaction could be estimated (Figure 3 ). The proposed model was $\mathrm{Z}=\left(128697.57+75.87 \mathrm{X}+2.9721 \mathrm{e}^{-6} \mathrm{X}^{2}\right.$ $-9.71 \mathrm{XY}) /(57998.92+\mathrm{X})$, in which the linear, quadratic, interaction and hyperbolic effects are observed ( Figure 3). Therefore, it is possible to verify that increasing castor oil concentration, the mortality of coffee berry borer reduced regardless $B$. bassiana concentration (Figure 3 ). Therefore, it was found that there was no effect of castor oil on $H$. hampei (Figure 3). Castor oil had an antagonistic effect on $B$. bassiana (Figure 3).

\section{DISCUSSION}

Low mortality observed with castor oil in absence of $B$. bassiana is probably correlated to the high relative humidity required to set up an experiment with entomopathogenic fungi. Unlike the results obtained in this research, castor oil, at a concentration of $3.0 \%\left(\mathrm{v} \mathrm{v}^{-1}\right)$ of the cultivar IAC 80 and Paraguaçu, caused 57.29 and $44.03 \%$ of coffee berry borer mortality, respectively (Celestino et al., 2015). In research comparing the mortality of the $H$. hampei caused by vegetable and mineral oils, it was found that in the concentration of $3.0 \%\left(\mathrm{v} \mathrm{v}^{-1}\right)$ castor oil and neem oil, caused 53.7 and $40.8 \%$ mortality, respectively (Celestino et al., 2016a). It may contribute to increase formation of droplets, preventing the coating of coffee berry borer female by oil. Also, the probable action of castor oil is due to spiracles coating and/or tracheas causing insect death by asphyxia (Celestino et al., 2016a), the relative humidity may have directly influenced the action of this oil on coffee berry borer mortality.

Although castor oil derivatives have insecticidal action on some pest-insects (Bigi et al., 2004; Ramos-López et al., 2010; Arnosti et al., 2011; Tounou et al., 2011; Nascimento et al., 2011; Celestino et al., 2015; 2016a; Machado et al., 2020), there are few studies that evaluate the interaction between castor oil derivatives and entomopathogenic fungi. However, Rondelli et al. (2011) found that when castor oil at $2 \% \mathrm{v} \mathrm{v}^{-1}$ was added, suspensions of the ESALQ-447 isolate and the formulated Boveril ${ }^{\circledR}$ PM (ESALQ-PL63 isolate) (Company: KOPPERT, Itapetininga, SP) at $3 \times 10^{5}$ conidia $\mathrm{mL}^{-1}$, the mortality of Plutella xylostella (L.) (Lepidoptera: Plutellidae) were significantly higher compared to the use of these methods in isolation, a result opposite to that observed in the present study, probably due to the feeding habits.

Despite the increase in mortality presented by ESALQ-447 isolate, previously reported in an in vitro compatibility test, castor oil in concentrations of $0,5,1,0,1,5$, $2,0,2,5$ and $3,0 \% \mathrm{v} \mathrm{v}^{-1}$ was moderately toxic to this isolate (Celestino et al., 2018). Conversely, B. bassiana CCA-UFES/ $\mathrm{Bb}-4$ isolate, whose castor oil was moderately toxic only at $3.0 \% \mathrm{v} \mathrm{v}^{-1}$ (Celestino et al., 2018), in the in vivo test this oil negatively affected the fungi performance on $H$. hampei mortality, in concentrations below $1 \times 10^{7}$ conidia $\mathrm{mL}^{-1}$ (Figure 1). However, when fungi concentration was increased, i.e., inoculum amount, there was no interference in the total mortality of coffee berry borer; and in the confirmed mortality, although there was a reduction, it was less significant than that presented in lower fungi concentrations. Such fact makes possible to use these management methods in association if both concentrations are observed. Therefore, a field evaluation is necessary to determine the efficiency of these methods depending on local climatic conditions, which will enable a better analysis of the relationship between increased fungi concentration, interaction with castor oil and efficiency on coffee berry borer control.

Unlike castor oil that demonstrated antagonism to $B$. bassiana on coffee berry borer control, neem oil, despite reports in vitro fungitoxic effects to $B$. bassiana (Depieri; Martinez; 
Menezes, 2005; Moran et al., 2007; Araujo JR; Marques; Oliveira, 2009; Islam; Olleka; Ren, 2010), when applied in association with this fungi, showed greater ovicidal action on Bemisia tabaci (Gennadius) (Hemiptera: Aleyrodidae) eggs and reduced the lethal time $\left(\mathrm{TL}_{50}\right)$ of nymph mortality (Islam; Castle; Ren, 2010). However, genetic variability of $B$. bassiana may influence the interaction of this fungi with neem oil (Mohan et al., 2007). Since, when Margoside ${ }^{\circledR}$ formulated at $0,3 \% \quad \mathrm{v} \mathrm{V}^{-1}$ (Active ingredient: $0.15 \%$ azadiractina; Company: M/s Monofix Agroproducts Ltd, Hubli, India) was associated with $B$. bassiana, additive and antagonistic effects were observed on mortality of caterpillars of Spodoptera litura (F.) (Lepidoptera: Noctuidae) in response to fungi isolate used (Mohan et al., 2007). Thus, in vivo compatibility studies with other $B$. bassiana isolates should be performed, as it is possible to exist isolates less sensitive to castor oil action.

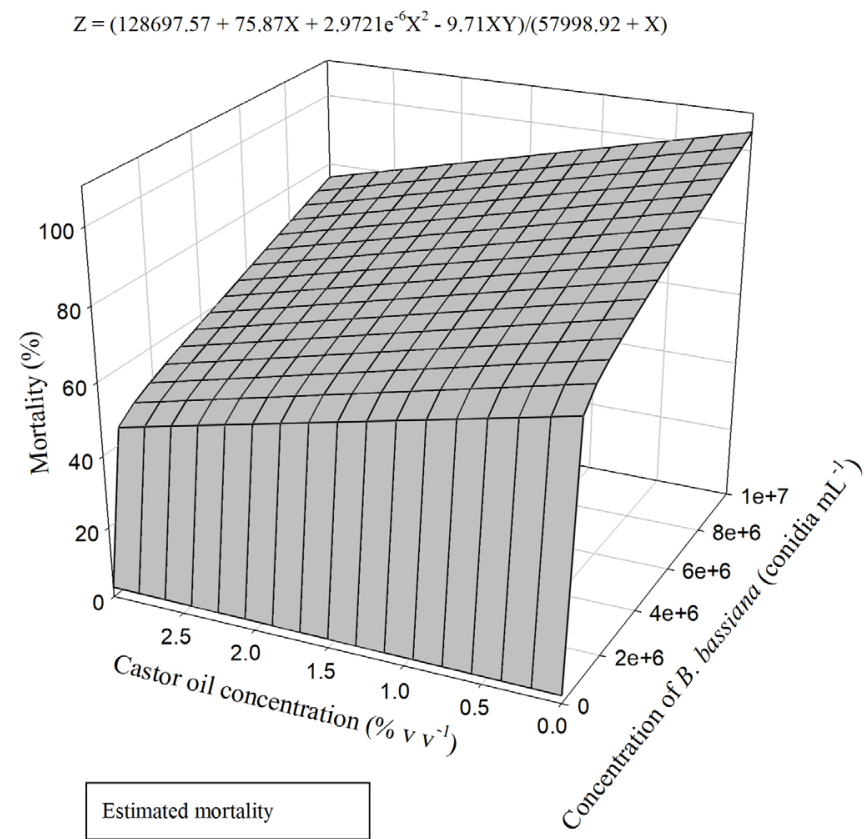

Figure 3: Response surface model for Hypothenemus hampei mortality caused by the interaction between castor oil and Beauveria bassiana, at $25 \pm 1{ }^{\circ} \mathrm{C}, \mathrm{RH}$ of $70 \pm 10 \%$ and $12 \mathrm{~h}$ photophase.

\section{CONCLUSIONS}

Castor oil presented an antagonistic effect on $B$. bassiana, reducing the coffee berry borer mortality. Mortality of $H$. hampei caused by interaction between $B$. bassiana and castor oil, decreased in response to increasing concentration of castor oil. Less interference of castor oil was observed for highest $B$. bassiana concentrations. Based on the results, management of $H$. hampei cannot be normally performed using the association between castor bean oil and B. bassiana, except if the economic viability of the higher concentrations justified.

\section{ACKNOWLEDGEMENTS}

The authors are grateful to the Conselho Nacional de Desenvolvimento Científico e Tecnológico (CNPq), the Fundação de Amparo à Pesquisa do Espírito Santo (Fapes), the Coordenação de Aperfeiçoamento de Pessoal de Nível Superior (Capes) and the Núcleo de Desenvolvimento Científico e Tecnológico em Manejo Fitossanitário (Nudemafi) for their financial support of this study.

\section{REFERENCES}

ALVES, R.T.; FARIA, M. Pequeno manual sobre fungos entomopatogênicos. Documento 286, Planaltina: Embrapa Cerrados, 2010. 50p.

ARAUJO JR, J. M. de.; MARQUES, E. J.; OLIVEIRA, J. $\mathrm{V}$. de. Potencial de isolados de Metarhizium anisopliae e Beauveria bassiana e do Óleo de Nim no Controle do Pulgão Lipaphis erysimi (Kalt.) (Hemiptera: Aphididae). Neotropical Entomology, 38(4):520-525, 2009.

ARNOSTI, A. et al. Effects of ricinoleic acid esters from castor oil of Ricinus communis on the vitellogenesis of Rhipicephalus sanguineus (Latreille, 1806) (Acari: Ixodidae) ticks. Experimental Parasitology, 127(2):575$580,2011$.

BIGI, M. F. M. A. et al. Activity of Ricinus communis (Euphorbiaceae) and ricinine against the leaf-cutting ant Atta sexdens rubropilosa (Hymenoptera: Formicidae) and the symbiotic fungus Leucoagaricus gongylophorus. Pest Management Science, 60(9):933-938, 2004.

CAMPOS, E. V. R. et al. Use of botanical insecticides for sustainable agriculture: Future perspectives. Ecological Indicators, 105:483-495, 2019.

CELESTINO, F. N. et al. Toxicidade do óleo de mamona à broca-do-café [Hypothenemus hampei (FERRARI) (COLEOPTERA: CURCULIONIDAE: SCOLYTINAE)] [Toxicity of castor oil to coffee berry borer [Hypothenemus hampei (FERRARI) (COLEOPTERA: CURCULIONIDAE: SCOLYTINAE)]]. Coffee Science, 10(3):329 - 336, 2015.

CELESTINO, F. N. et al. Control of coffee berry borer, Hypothenemus hampei (Ferrari) (Coleoptera: Curculionidae: Scolytinae) with botanical insecticides and mineral oils. Acta Scientiarum. Agronomy, 38(1):1-8, $2016 \mathrm{a}$.

CELESTINO, F. N. et al. Adaptação de técnicas de criação da broca-do-café [Hypothenemus hampei (Ferrari)] [Adaptation of technique for rearing of the coffee berry borer [Hypothenemus hampei (Ferrari)]]. Coffee Science, 11(2):161-168, $2016 \mathrm{~b}$. 
CELESTINO, F. N. et al. Compatibilidade in vitro entre Beauveria bassiana e o óleo de mamona. Revista Brasileira de Ciências Agrárias, 13(4):e5595, 2018.

CORREAL, C. E. et al. Hongos entomopatógenos en el control biológico de insectos plaga. In: COTES, A. M. Control biológico de fitopatógenos, insectos y ácaros. Mosquera, (Colombia): Agrosavia, 2018. 568p.

DALVI, L. P. et al. Selection of native isolates of Beauveria bassiana (Ascomycota, Hypocreales) for the control of the coffee borer beetle Hypothenemus hampei (Scolytinae) in Brazil. Biological Letters, 48(1):39-46, 2011.

DARA, S. K. The New Integrated Pest Management Paradigm for the Modern Age. Journal of Integrated Pest Management, 10(1):1-9, 2019.

DEPIERI, R. A.; MARTINEZ, S. S.; MENEZES JR. A. O. Compatibility of the Fungus Beauveria Bassiana (Bals.) Vuill. (Deuteromycetes) with Extracts of Neem Seeds and Leaves and the Emulsible Oil. Neotropical Entomology, 34(4):601-606, 2005.

FANG, W. et al. Cloning of Beauveria bassiana chitinase gene Bbchit1 and its application to improve fungal strain virulent. Applied and Environmental Microbiology, 71(1):363-370, 2005.

ISLAM, M. T.; CASTLE, S. J.; REN, S. Compatibility of the insect pathogenic fungus Beauveria bassiana with neem against sweetpotato whitefly, Bemisia tabaci, on eggplant. Entomologia Experimentalis et Applicata, 134(1):2834, 2010.

ISLAM, M. T.; OLLEKA, A.; REN, S. Influence of neem on susceptibility of Beauveria bassiana and investigation of their combined efficacy against sweetpotato whitefly, Bemisia tabaci on eggplant. Pesticide Biochemistry and Physiology, 98(1):45-49, 2010.

ISLAM, M.T.; OMAR, D. B. Combined effect of Beauveria bassiana with neem on virulence of insect in case of two application approaches. The Journal of Animal \& Plant Sciences, 22(1):77-82, 2012.

ISMAN, M. B.; GRIENEISEN, M. L. Botanical insecticide research: many publications, limited useful data. Trends in Plant Science - Cell Press, 19(3):140-145, 2014.

MACHADO, L. C. et al. Toxicidade de óleos minerais e vegetais no manejo de Planococcus citri [Toxicity of mineral and vegetable oils in management of Planococcus citri]. Acta Ambiental Catarinense, 17(1):63-72, 2020.

MINISTÉRIO DA AGRICULTURA, PECUÁRIA E ABASTECIMENTO - MAPA. Valor Bruto da Produção
Agropecuária de 2019 é atualizado para R\$ 609,5 bilhões. 2019. Available in: <https:/www.gov.br/pt-br/ noticias/agricultura-e-pecuaria/2019/11/valor-bruto-daproducao-agropecuaria-de-2019-e-atualizado-para-r-6095-bilhoes>. Access in: May,18, 2020a.

MINISTÉRIO DA AGRICULTURA, PECUÁRIA E ABASTECIMENTO - MAPA. AGROFIT: Sistema de agrotóxicos fitossanitários. 2020. Available in: <http:// agrofit.agricultura.gov.br/agrofit_cons/principal_agrofit cons $>$. Access in: May, 18, 2020 b.

MOHAN, M. C. et al. Growth and insect assays of Beauveria bassiana with neem to test their compatibility and synergism. Biocontrol Science and Technology, 17(10):1059-1069, 2007.

MOLINA, D. et al. Effects of the aspartic protease inhibitor from Lupinus bogotensis seeds on the growth and development of Hypothenemus hampei: An inhibitor showing high homology with storage proteins. Phytochemistry, 98:69-77, 2014.

NASCIMENTO, V. V. DO et al. In silico structural characteristics and $\alpha$-amylase inhibitory properties of Ric c 1 and Ric c 3, allergenic $2 \mathrm{~S}$ albumins from Ricinus communis seeds. Journal of Agricultural and Food Chemistry, 59(9):4814-4821, 2011.

INTERNATIONAL COFFEE ORGANIZATION - OIC. Growing Prosperity - Economic viability as the catalyst for a sustainable coffee sector. 2019. London: International Coffee Organization - Coffee Development Report, Available at: <http://www.ico.org/documents/ cy2018-19/ed-2318e-overview-flagship-report.pdf>. Accessed on: May, 18, 2020.

OLIVEIRA, C. M. et al. Economic impact of exotic insect pests in Brazilian agriculture. Journal of Applied Entomology, 137(1-2): 1-15, 2013.

OVERMEER, W. P. J.; VAN ZON, A. Q. A standardized method for testing the side effect of pesticides on the predaceous mite, Amblyseius potentillae (Acari: Phytoseiidae). Entomophaga, 27(4):357- 364, 1982.

PEDRINI, N. et al. Molecular characterization and expression analysis of a suite of cytochrome P450 enzymes implicated in insect hydrocarbon degradation in the entomopathogenic fungus Beauveria bassiana. Microbiology, 156(8):25462557, 2010.

RAMOS-LÓPEZ, M.A. et al. Activity of Ricinus communis (Euphorbiaceae) against Spodoptera frugiperda (Lepidoptera: Noctuidae). African Journal of Biotechnology, 9(9): 1359-1365, 2010. 
RONDELLI, V. M. et al. Associação do óleo de mamona com Beauveria bassiana no controle da traça-das-crucíferas. Pesquisa Agropecuária Brasileira, 46(2):212-214, 2011.

SAMPER, L.; GIOVANNUCCI, D.; MARQUES VIEIRA, $\mathrm{L}$. The powerful role of intangibles in the coffee value chain. Geneva: World Intellectual Property Organization - Economics and Statistics Division, 2017. Available in: <https://www.wipo.int/edocs/ pubdocs/en/wipo_pub_econstat_wp_39.pdf $>$. Access in: May, 18, 2020.

SWATHI, P.; VISALAKSHY, P. N. G.; DAS, S. B. In vitro evaluation for compatibility of additives with Beauveria bassiana (Balsamo) Vuillemin. Egyptian Journal of Biological Pest Control, 28(13):1-5, 2018.

TOUNOU, A.K. et al. Bio-insecticidal effects of plant extracts and oil emulsions of Ricinus communis L. (Malpighiales: Euphorbiaceae) on the diamondback,
Plutella xylostella L. (Lepidoptera: Plutellidae) under laboratory and semi-field conditions. Journal of Applied Biosciences, 43(3):2899-2914, 2011.

VEGA, F. E. et al. The coffee berry borer, Hypothenemus hampei (Ferrari) (Coleoptera:Curculionidae): a short review, with recent findings and future research directions. Terrestrial Arthropod Reviews, 2(2):129$147,2009$.

VEGA, F.E. et al. On the Eyes of male coffee berry borers as rudimentary organs. PLoS ONE, San Francisco, 9(1):858-860, 2014.

ZHANG, S. et al. CYP52X1, representing new cytochrome P450 subfamily, display fatty acid hydroxylase activity and contributes to virulence and growth on insect cuticular substrates in entomopathogenic fungus Beauveria bassiana. Journal of Biological Chemistry, 287(16):13477-13486, 2012. 